\title{
Children, young people and requests for police station legal advice - 25 years on from PACE
}

\author{
Kemp, V., Pleasence, P. and Balmer, N. J. Youth Justice (April, 2011)
}

\begin{abstract}
Informed by data extracted from 30,921 police electronic custody records, drawn from 44 police stations across four police force areas and including 5,153 records of juveniles aged 10 to 17 years, this article examines the take-up of legal advice by children and young people in police stations in England and Wales. There are wide variations in the extent to which juveniles request and receive legal advice when compared to adults but also between juveniles of different ages. Such variations are explored both in relation to the age of detainees and the type and seriousness of offence and case disposal. Also examined are variations based on different police force areas. The implications emanating from children's differential access to legal advice at police stations are considered in relation to children's rights.
\end{abstract}

\section{Key words}

Children's rights, decision-making, doli incapax, final warnings, police station legal advice.

\section{Introduction}

2011 marks the $25^{\text {th }}$ anniversary of the implementation of the Police and Criminal Evidence Act (PACE), which provides that those detained by the police have a right to free and independent legal advice. ${ }^{1}$ The Act has had a profound effect on access to advice in the police station. Prior to PACE, estimates of the rate at which detainees requested legal advice ranged from 3\% to 20\% (see Softley et al., 1980; Bottomley et al., 1989; Brown, 1991). Since PACE, the rate has slowly increased, from 25\% in 1987 (Brown, 1989), to 32\% in the early 1990s (Brown et al., 1992), to $40 \%$ in 1995/96 (Bucke and Brown, 1997) and to around $45 \%$ presently (Pleasence et al., 2011). However, despite the right to legal advice constituting a key safeguard to procedural propriety - a matter of particular importance in relation to so-called 'vulnerable' detainees (including children/juveniles) - there is limited evidence around the use of advice by children and young people in the police station.

There is some broad indication of how frequently juveniles request advice. For example, Phillips' and Brown's (1998) study of 1993/4 custody records found that juveniles requested advice at a lower rate than adults (33\% compared to 39\%). However, they suggested that the lower take-up of legal advice was due to juveniles being dealt with for less serious offences than adults. When later examining 1995/96 custody records, Bucke and Brown (1997) found that, for the first time, the request rates of juveniles had overtaken that of adults $(41 \%$ compared to $39 \%$ respectively).

In neither of the mid-1990's studies was consideration given to the possibility that the advice take-up rates of juveniles might vary by age. This may be because the presumption of

\footnotetext{
${ }^{1}$ Section 58(1) of PACE introduced the unequivocal right of detainees to obtain legal advice. The right to advice was further strengthened in April 1991 with revised Code $\mathrm{C}$ requiring detainees to be told 'clearly' about their right to 'free and independent legal advice' (para. 3.1). Police station legal advice can be provided by a practicing solicitor or an accredited or probationary representative.
} 
doli incapax ${ }^{2}$ applied at that time, which meant that very few 10 to 13 year olds were drawn into the formal criminal justice system and there was a greater emphasis placed on diverting children and young people from court (see Goldson, 2000). However, this was to change with the Crime and Disorder Act 1998, which brought about a more rigid and punitive youth justice system (see Home Office, 1997). Changes included abolition of the presumption of doli incapax, with children aged 10 to 13 years now presumed to have the same level of understanding as adults. ${ }^{3}$ The 1998 Act also introduced the Final Warning scheme, which replaced the system of cautioning for juveniles. Within this new context of pre-charge decision-making, the need to ensure that the legal rights of children are properly protected within the early stages of the criminal justice process becomes more urgent (Goldson, 2000).

Furthermore, in light of Pleasence et al.'s (2011) recent finding that - after controlling for seriousness and type of offence, police station, police force area and basic demographic factors - those aged 10 to 13 years request/have access to legal advice less frequently than others, the need for further investigation is self-evident.

This article sets out a more detailed picture of the take-up of legal advice by young detainees in police stations in England and Wales, and provides a better basis for considering the current treatment of the youngest persons susceptible to criminal proceedings. We examine requests for legal advice by juvenile detainees of different ages, with reference to the type and seriousness of offence and the outcome of detention. We also look at the extent to which legal advice is actually received and how this might vary between different police force areas.

\section{Methods}

This study is based on data extracted from 30,921 police electronic custody records, drawn from 44 police stations across four police force areas, ${ }^{4}$ including 5,153 records of juveniles aged 10 to 17 years. The data include details of all new cases brought into the police stations during the months of March and September 2009. Details include the type of offence, details of the individual, whether or not legal advice was requested and the outcome of detention.

First, overall rates of requesting advice were established for juvenile and adult detainees, treating all detention periods separately, looking only at first detentions and also at individuals across all detentions.

Second, regression analysis was used to establish whether the rate of requesting advice varied in accordance with the age of juvenile detainees, after controlling for offence seriousness, gender, ethnicity, ${ }^{5}$ police station, police force area, and detention period. ${ }^{6}$ Offence seriousness was recorded using a scale from one (least serious) to four (most

\footnotetext{
${ }^{2}$ The presumption of doli incapax was that a child aged 10 to 13 was incapable of a crime and that the prosecution needed to rebut the presumption before charging a child.

${ }^{3}$ Indeed, having had their legal safeguards removed 10 to 13 year olds are judged as being as culpable as any adult offender (Bandalli, 1998 and 2000; Goldson and Muncie, 2006).

${ }^{4}$ The 30,921 electronic custody records relate to 25,005 individuals.

${ }^{5}$ In the regression analysis is included the 'ethnic appearance' of the detainee. This is based on the custody officers' assumption of the ethnic background of the detainee rather than on the ethnicity reported by the detainee.

${ }^{6}$ A three-level multilevel model was used since the data was hierarchical, with charge nested within detainee, and detainee within police station. This meant that the model also accounted for clustering by detainee and police station. Predictors were fitted as main effects only.
} 
serious), derived from the gravity scores set out by the Home Office (2006) in guidance to assist police officers when deciding whether to reprimand, warn or charge young offenders. With a gravity score of one the police are encouraged to always take the minimum response applicable to the individual, while a score of four usually requires the police to charge. Where possible, the gravity scores were applied to the offences detailed in the database. Where offences were not included in the Home Office guidance, a score was allocated to match similar offence types which are included. Statistical output and a full list of the detainee, offence and police station variables included in the regression analyses are set out in Table A in the statistical appendix.

Third, the rate at which juveniles of different ages and adults requested advice for offences was explored in greater detail, by offence seriousness, type of offence, police force area and outcome. Three categories were used to describe the outcome of detention: no further action, pre-court disposal and charge. The category of 'pre-court disposals' mainly includes reprimands and warnings for juveniles and simple and conditional cautions for adults, although increasingly the police are using fixed penalty notices (FPN) and penalty notices for disorder (PND) (see Morgan, 2008). ${ }^{7}$ However, these latter two disposals are not usually recorded on the police custody database as they are sanctions handed out by the police on the street, with the details then being recorded on the Police National Computer. It is only in cases where someone has been arrested and detained by the police, and a FPN or PND is then issued, that it is also recorded on the police custody record.

Fourth, we established the rate at which juveniles of different ages and adults obtained advice following a request being made. This information was drawn from a sub-sample of 2,781 cases, where advice was requested - including 382 aged 10 to 17 years - spread across 15 larger police stations in four areas.

Our findings are discussed in the context of the broader literature and with reference to current policy debates.

\section{Findings}

The age of detainees and requests for legal advice

Across all four police force areas studied, $45.3 \%$ of detainees (counting each detention period separately) requested advice, with $77.5 \%$ of requests resulting in legal consultations $(35.1 \%$ overall). The figures for suspects were $44.9 \%$ and $81.3 \%$ respectively (36.5\% overall), and for other detainees $49.8 \%$ and $50.6 \%$ respectively $\left(25.2 \%\right.$ overall). ${ }^{8}$ When just juveniles (aged 10 to 17 years) were looked at, $45.0 \%$ of detainees (counting each detention period separately) requested advice, with $74.9 \%$ of requests resulting in legal consultations $(33.7 \%$ overall). The figures for suspects were $44.7 \%$ and $76.6 \%$ respectively (34.2\% overall), and for other detainees $53.1 \%$ and $53.6 \%$ respectively (28.5\% overall). Thus, there was little difference in the overall picture for adult and juvenile detainees.

If only first arrests were included, then the overall request rate for juveniles dropped slightly to $42.4 \%$, with $81.5 \%$ of requests leading to legal consultations ( $34.6 \%$ overall). Alternatively, if individual juvenile detainees were looked at across all detention periods,

\footnotetext{
${ }^{7}$ There is apparently no evidence that PNDs have displaced reprimands to a significant extent (Youth Justice Board and Ministry of Justice, 2010).

${ }^{8}$ Other detainees include those being dealt with for Bail Act offences, Mental Health interventions and immigration matters.
} 
then $42.6 \%$ requested advice, with $83.6 \%$ of detainees making requests going on to have legal consultations (35.6\% overall). Again, no difference between adults and juvenile detainees was observed.

As stated above, detailed findings from the regression analysis, which explored the likelihood of requesting a solicitor on the basis of age, gender, ethnic appearance, police force area and gravity score are set out in Table A in the Statistical Appendix. ${ }^{9}$ After controlling for other factors, the regression analysis pointed to the advice-request-rate for young people peaking at 16 years of age, with significantly lower rates observed for 17 year olds and younger detainees (see Table A). Treating age as a categorical predictor, compared to the 17 year old reference category, 15 and, particularly, 16 year olds were significantly more likely to request a solicitor (testing the two terms gave $\chi^{2}{ }_{1}=4.14, p=0.042$ and $\chi^{2}{ }_{1}=$ $27.86, \mathrm{p}<0.001$ respectively, both statistically significant). Ten to 14 year olds were not significantly different to 17 year olds. In the case of 10 year olds, while the estimate was low $(22.7 \%)$, this was based on very small numbers of detainees (thus the wide confidence interval). Just over half of 16 year old detainees requested a solicitor (51.3\% using raw data or $50.6 \%$ when simulated from the regression model). The figure dropped to 41.2 percent (39.9\% when simulated from the model) for 17 year olds.

Figure 1 shows the simulated probability of requesting a solicitor based on the regression model in Table A. After the age of 17 the request rate slowly moved towards a plateau, commencing in the mid-20s, of around $47 \%$.

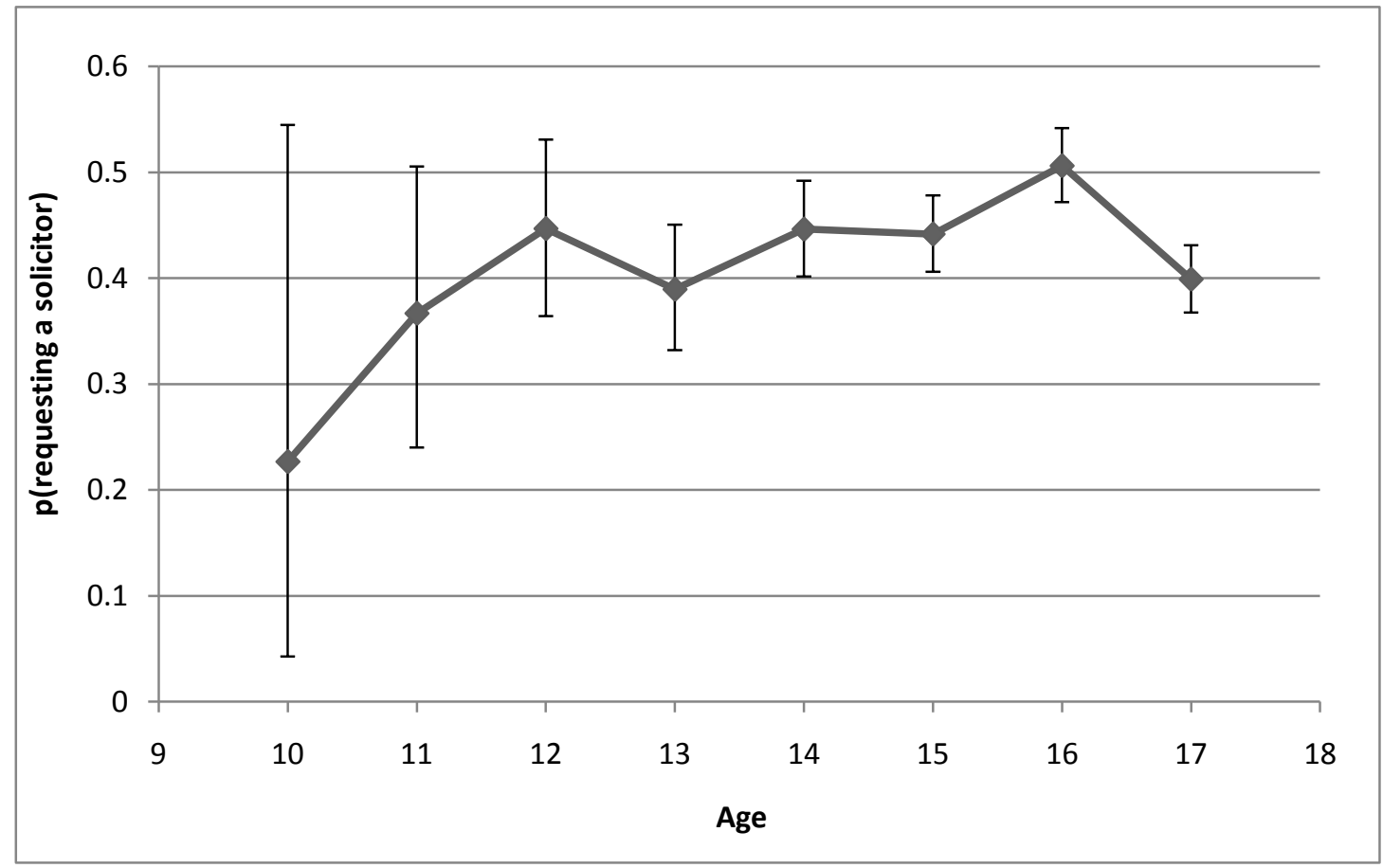

Figure 1: Simulated probability of requesting a solicitor by age using the model in Table A.

Other demographic factors and requests for legal advice

\footnotetext{
${ }^{9}$ The model also includes random terms accounting for clustering by detainee and police station.
} 
There was no statistically significant difference in the rate at which juvenile detainees requested advice on the basis of gender. Although, overall, young female detainees were found to request legal advice less often than males, this was largely explained by other factors, such as the different profile of offences for which they were being dealt with. However, there was some evidence of ethnicity having an impact on requesting a solicitor. Compared to the reference category 'white European', Black respondents were significantly more likely to request a solicitor $\left(\chi^{2}{ }_{1}=14.41, \mathrm{p}<0.001\right)$. This ties in with our findings reported across detainees of all ages (Pleasence et al. 2011). No other significant differences based on ethnicity were observed, although the number of detainees in many ethnic minority categories was small.

\section{Offence seriousness and requests for legal advice}

The proportions of detainees who were being dealt with for offences of different seriousness are set out in Table 1. As can be seen, younger respondents were being dealt with for fewer offences in both the lowest and highest seriousness categories. In fact, out of 554 children aged 10 to 13 years just five were being dealt with for the most minor offences. For these youngest respondents offences in the second seriousness category were the most common.

Table 1: Proportion of detainees being dealt with by offence seriousness and age

\begin{tabular}{|c|c|c|c|c|c|}
\hline \multirow{3}{*}{ Offence seriousness } & \multicolumn{5}{|l|}{ Age } \\
\hline & $18+$ & $10-17$ & $16-17$ & $14-15$ & $10-13$ \\
\hline & $\%$ & $\%$ & $\%$ & $\%$ & $\%$ \\
\hline $1(\mathrm{n}=1194)$ & 4.5 & 2.6 & 3.4 & 1.9 & 0.9 \\
\hline $2(n=9791)$ & 34.7 & 40.0 & 38.4 & 41.6 & 42.3 \\
\hline $3(n=9123)$ & 33.0 & 33.9 & 33.9 & 33.3 & 36.0 \\
\hline $4(n=7413)$ & 27.8 & 23.5 & 24.3 & 23.2 & 20.8 \\
\hline Total $(n=27521)$ & 100 & 100 & 100 & 100 & 100 \\
\hline
\end{tabular}

As indicated in Table A in the Statistical Appendix, offence seriousness was a crucial driver of requests for legal advice. Elsewhere, we have shown that it plays a far greater role than offence type (Pleasence et al. 2011). This is clearly evident in Table 2, which sets out the rate at which advice was requested by offence seriousness and age of detainee. Request rates increased markedly with offence seriousness for all age groups.

Table 2: Requests for legal advice by offence seriousness and by age

\begin{tabular}{|c|c|c|c|c|c|}
\hline \multirow[t]{2}{*}{ Offence seriousness } & \multicolumn{5}{|l|}{ Age } \\
\hline & $\begin{array}{l}18+ \\
\mathrm{n}=22500 \\
\%\end{array}$ & $\begin{array}{l}10-17 \\
\mathrm{n}=4835 \\
\%\end{array}$ & $\begin{array}{l}16-17 \\
\mathrm{n}=2601 \\
\%\end{array}$ & $\begin{array}{l}14-15 \\
\mathrm{n}=1693 \\
\%\end{array}$ & $\begin{array}{l}10-13 \\
\mathrm{n}=554 \\
\%\end{array}$ \\
\hline 1 & 22.2 & 26.4 & 27.3 & 28.1 & - \\
\hline 2 & 37.3 & 36.9 & 37.8 & 36.6 & 34.0 \\
\hline 3 & 47.1 & 43.7 & 44.2 & 45.0 & 37.4 \\
\hline 4 & 56.2 & 62.1 & 62.9 & 63.3 & 53.5 \\
\hline Overall & 45.1 & 44.9 & 45.7 & 45.4 & 39.0 \\
\hline
\end{tabular}


Reflecting the link between request rates and age detailed in the previous section, advice rates for 10 to 13 year old detainees were the lowest across all levels of seriousness. Of note, however, the greatest discrepancy in rates for 10 to 13 year olds appeared to be in relation to the most serious offences.

\section{Offence type and requests for legal advice}

Table 3 sets out the type of offences (or other reason) for which individuals in different age groups were detained. ${ }^{10}$ Consistent with the official statistics, the high-volume offences committed by juveniles included violence against the person, theft and handling, criminal damage and Public Order Act offences (Youth Justice Board and Ministry of Justice, 2010). There were other types of offences which mainly involved older detainees, such as homicide, motoring and drug offences and fraud and forgery. ${ }^{11}$

Table 3: Proportion of detainees being dealt with by different offence types and by age

\begin{tabular}{|c|c|c|c|c|c|}
\hline \multirow[t]{3}{*}{ Offence type } & \multicolumn{5}{|l|}{ Age } \\
\hline & $18+$ & $10-17$ & $16-17$ & $14-15$ & $10-13$ \\
\hline & $\%$ & $\%$ & $\%$ & $\%$ & $\%$ \\
\hline Homicide $(n=47)$ & 0.2 & $<0.0$ & 0.1 & 0 & 0 \\
\hline Violent offences $(n=7816)$ & 25.5 & 24.6 & 22.5 & 26.3 & 30.1 \\
\hline Sexual offences $(n=1044)$ & 3.6 & 2.6 & 2.1 & 2.5 & 5.6 \\
\hline Burglary $(n=1989)$ & 5.4 & 11.7 & 12.5 & 11.6 & 7.9 \\
\hline Robbery (n=665) & 1.4 & 5.8 & 4.1 & 8.2 & 6.5 \\
\hline Motor theft (514) & 1.4 & 3.2 & 3.5 & 3.4 & 1.6 \\
\hline Theft \& handling $(n=4696)$ & 14.9 & 17.1 & 16.1 & 18.2 & 18.4 \\
\hline Fraud and forgery $(n=595)$ & 2.2 & 0.4 & 0.7 & 0.1 & 0 \\
\hline Criminal damage $(\mathrm{n}=2539)$ & 7.1 & 13.5 & 12.8 & 12.7 & 19.3 \\
\hline Drugs offences $(n=1991)$ & 6.8 & 4.8 & 6.7 & 3 & 0.9 \\
\hline POA offences $(n=2590)$ & 8.4 & 8 & 8.8 & 7.2 & 6.1 \\
\hline All other offences $(n=1638)$ & 5.6 & 2.9 & 3.1 & 3.1 & 1.4 \\
\hline Motoring offences $(n=1941)$ & 7.4 & 1.0 & 1.7 & 0.1 & 0.4 \\
\hline Administrative $(n=2108)$ & 7.5 & 3.5 & 4.4 & 2.8 & 1.0 \\
\hline Non-PACE $(n=712)$ & 2.6 & 0.8 & 0.9 & 0.8 & 0.5 \\
\hline Total $(n=30855)$ & 100 & 100 & 100 & 100 & 100 \\
\hline
\end{tabular}

Set out in Table 4 are the request rates for legal advice by age and offence type. The offence types for children have been excluded where there were no cases (e.g. homicide and

\footnotetext{
${ }^{10}$ It is not known what offence types the police classify as 'other offences'. Included in the 'administrative' category are mainly Bail Act offences and in 'non-PACE' are mainly immigration cases and people detained under the Mental Health Act provisions. Due to the rounding of fractions, it should be noted that the total columns may not add to $100 \%$.

${ }^{11}$ There are fewer than 10 children aged 10 to 13 years involved in the categories of motor theft, drugs, other offences, motoring, administrative and non-PACE matters.
} 
fraud and forgery) and also in six categories where there were fewer than 10 children aged 10 to 13 years involved. ${ }^{12}$

Table 4: Requests for legal advice by offence type and age

\begin{tabular}{|c|c|c|c|c|c|}
\hline \multirow[t]{2}{*}{ Offence Type } & \multicolumn{5}{|l|}{ Age } \\
\hline & $\begin{array}{l}18+ \\
\mathrm{n}=22518 \\
\%\end{array}$ & $\begin{array}{l}10-17 \\
\mathrm{n}=5153 \\
\%\end{array}$ & $\begin{array}{l}16-17 \\
\mathrm{n}=2811 \\
\%\end{array}$ & $\begin{array}{l}14-15 \\
\mathrm{n}=1788 \\
\%\end{array}$ & $\begin{array}{l}10-13 \\
\mathrm{n}=554 \\
\%\end{array}$ \\
\hline Homicide & 82.2 & 100.0 & 100.0 & - & - \\
\hline Violent offences & 47.3 & 43.2 & 42.1 & 44.8 & 43.1 \\
\hline Sexual offences & 58.8 & 68.7 & 76.3 & 59.1 & 67.7 \\
\hline Burglary & 57.8 & 55.6 & 60.0 & 53.1 & 31.8 \\
\hline Robbery & 62.0 & 64.2 & 62.1 & 71.4 & 41.7 \\
\hline Motor theft & 51.9 & 55.7 & 55.1 & 58.3 & - \\
\hline Theft \& handling & 41.4 & 35.1 & 36.7 & 34.6 & 29.4 \\
\hline Fraud and forgery & 57.3 & 47.8 & 52.4 & - & - \\
\hline Criminal damage & 40.9 & 39.4 & 44.0 & 37.0 & 29.0 \\
\hline Drugs offences & 50.3 & 38.5 & 37.0 & 43.4 & - \\
\hline Public order offences & 36.6 & 39.5 & 40.9 & 34.1 & 50.0 \\
\hline All other offences & 37.1 & 47.0 & 39.5 & 56.4 & - \\
\hline Motoring offences & 33.2 & 37.3 & 31.9 & 100 & - \\
\hline Administrative & 53.8 & 57.5 & 59.2 & 56.0 & - \\
\hline Non-PACE & 37.1 & 34.9 & 30.8 & 42.9 & - \\
\hline Overall & 45.4 & 45.0 & 45.8 & 45.7 & 39.0 \\
\hline
\end{tabular}

Overall there was a very similar request rate for legal advice when comparing juveniles and adults, although, in keeping with our findings around age in general, there were marked differences for certain types of offences. In relation to high-volume offences, such as violence and theft and handling, for instance, a noticeably higher proportion of adults requested legal advice, when compared to juveniles. There were also higher request rates for adults in relation to fraud and forgery and drug offences. However, in relation to sexual offences and Public Order Act offences, juveniles were seen to have a higher request rate than adults.

There are, however, limitations when considering variations in request rates based on the type of offence. Some categories, for example, incorporate a broad range of offences which can include both minor and serious matters, such as violence against the person and theft and handling offences. Similarly, there are limitations when examining the seriousness of offences as this too relies on a typology of offences. It is useful, therefore, to also consider variations based on the case outcome.

\section{Legal advice and the outcome of detention}

${ }^{12}$ Requests for legal advice by children in the omitted offence type categories are included in the total number of offences. 
Table 5 below sets out the outcomes of detention by age. While a similar proportion of adults and juveniles had no further action taken against them, a slightly higher proportion of juveniles received a pre-court disposal and fewer were charged. Once again, though, a different pattern emerged when examining outcomes by age in more detail. The proportion of detainees having no further action taken against them was at its highest with 16 and 17 year olds, but declined for the youngest detainees, with 10 to 13 year olds least likely to have no further action taken against them. The opposite occurred with pre-court disposals. However, it is not surprising that a higher proportion of 10 to 13 year olds received a precourt disposal, as the Final Warning scheme strictly limits, to two, the number of pre-court disposals prior to charge, and very young detainees are less likely to have previously come to the attention of the police (details of the Final Warning scheme are discussed below).

Table 5: Outcome of detention by age

\begin{tabular}{|c|c|c|c|c|c|}
\hline \multirow[t]{3}{*}{ Case outcome } & \multicolumn{5}{|l|}{ Age } \\
\hline & $18+$ & $10-17$ & $16-17$ & $14-15$ & $10-13$ \\
\hline & $\%$ & $\%$ & $\%$ & $\%$ & $\%$ \\
\hline No further action $(\mathrm{n}=8895)$ & 32.3 & 31.8 & 34.7 & 29.0 & 26.0 \\
\hline Pre-court disposal $(\mathrm{n}=5580)$ & 18.9 & 26.1 & 22.2 & 27.2 & 41.7 \\
\hline Charge $(n=13136)$ & 48.8 & 42.1 & 43.0 & 43.7 & 32.3 \\
\hline Total $(n=27611)$ & 100 & 100 & 100 & 100 & 100 \\
\hline
\end{tabular}

Table 6 sets out requests for legal advice by outcome of detention and age. A commonality across all age groups is that fewer detainees requested legal advice where detentions resulted in a pre-court disposal, and more did so where detentions culminated in either charge or no action being taken. When looking at juveniles as a whole, there was a notably higher advice request rate where detentions resulted in charge, as compared to adults. However, although this was also the case for the very youngest detainees, these detainees requested advice less often when detentions led to charge than older juvenile detainees.

Table 6: Requests for legal advice by outcome of detention and age

\begin{tabular}{l|ll|lll}
\hline Outcome of detention & \multicolumn{4}{l}{ Age } \\
\cline { 2 - 6 } & $\begin{array}{llll}18+ \\
\mathrm{n}=22559\end{array}$ & $\begin{array}{l}10-17 \\
\mathrm{n}=4861\end{array}$ & $\begin{array}{l}16-17 \\
\mathrm{n}=2617\end{array}$ & $\begin{array}{l}14-15 \\
\mathrm{n}=1714\end{array}$ & $\begin{array}{l}10-13 \\
\mathrm{n}=554\end{array}$ \\
& $\%$ & $\%$ & $\%$ & $\%$ & $\%$ \\
\hline No further action & 43.8 & 45.1 & 45.5 & 46.6 & 36.9 \\
Pre-court disposal & 28.4 & 23.3 & 23.2 & 22.3 & 25.7 \\
Charge & 50.9 & 56.7 & 56.2 & 58.2 & 54.3 \\
\hline Overall & 44.4 & 44.3 & 45.1 & 45.0 & 37.9 \\
\hline
\end{tabular}

Table 7 sets out the proportion of detainees who requested legal advice where detentions led to charge, by offence type. ${ }^{13}$ While, overall, Table 6 shows that a higher proportion of

\footnotetext{
${ }^{13}$ The categories where fewer than 10 children are involved have been excluded.
} 
juveniles than adults requested legal advice for charged offences, it is apparent from Table 7 that this is not so in relation to all offence types. With the heightened vulnerability of children aged 10 to 13 years who are drawn into the criminal process, it is of concern that they request advice less often than other juveniles in relation to serious offences such as robbery and burglary, and that this holds even where they are subsequently charged. ${ }^{14}$

Table 7: Requests for legal advice in charged cases by offence type and age

\begin{tabular}{l|rr|rrr}
\hline \multirow{2}{*}{ Advice requested } & \multicolumn{7}{|l}{ Age } \\
\cline { 2 - 7 } & \multicolumn{1}{|l}{$18+$} & $10-17$ & $16-17$ & $14-15$ & $10-13$ \\
\cline { 2 - 7 } & $\%$ & $\%$ & $\%$ & $\%$ & $\%$ \\
\hline Violent offences & 56.2 & 52.5 & 50.7 & 53.4 & 58.6 \\
Sexual offences & 72.3 & 89.1 & 100 & 88.9 & 75.0 \\
Burglary & 65.3 & 63.7 & 70.0 & 60.5 & 20.0 \\
Robbery & 70.6 & 74.2 & 73.3 & 80.0 & 52.6 \\
Theft and handling & 44.8 & 51.4 & 52.7 & 50.8 & 43.8 \\
Criminal damage & 48.4 & 53.4 & 57.8 & 50.5 & 45.2 \\
POA offences & 45.4 & 56.4 & 53.3 & 59.1 & 77.8 \\
\hline
\end{tabular}

Requests for legal advice and police force areas

There were considerable differences in the overall request rates observed in the four police force areas studied, ranging from $41.3 \%$ and $40.1 \%$, in Areas A and B respectively, to $49.2 \%$ and $52.5 \%$ in Areas C and D respectively. These differences between areas were significant even after controlling for offence seriousness and type, police station, and the demographic characteristics of detainees (Pleasence et al., 2011), and even when only juveniles were under examination (Table A in the Statistical Appendix). Table 8 sets out request rates for legal advice by police force area and by age.

Table 8: Requests for legal advice based on police force area and age

\begin{tabular}{l|ll|lll}
\hline Police force area & \multicolumn{4}{l}{ Age } \\
\cline { 2 - 6 } & $18+$ & $10-17$ & $16-17$ & $14-15$ & $10-13$ \\
& $\%$ & $\%$ & $\%$ & $\%$ & $\%$ \\
\hline Area A $(\mathrm{n}=9483)$ & 42.1 & 37.6 & 38.9 & 37.2 & 33.0 \\
\hline Area B $(\mathrm{n}=7991)$ & 40.4 & 39.6 & 38.4 & 44.0 & 31.3 \\
Area C $(\mathrm{n}=8728)$ & 52.4 & 53.2 & 53.1 & 55.0 & 47.6 \\
\hline Area D $(\mathrm{n}=4683)$ & 48.0 & 55.4 & 58.6 & 49.4 & 57.4 \\
\hline Overall $(\mathrm{n}=30885)$ & 45.5 & 45.0 & 45.8 & 45.7 & 39.0 \\
\hline
\end{tabular}

While in Areas B and C there were similar request rates by juveniles compared to adults, there was a lower request rate for juveniles in Area A and a higher rate in Area D. Ten to thirteen year olds had a lower request rate than all other age groups in three areas $(\mathrm{A}, \mathrm{B}, \mathrm{C})$, but higher than all but 16 to 17 year olds in Area D.

\footnotetext{
${ }^{14}$ While there is only a small number of children charged with these offence types (19 with robbery and 15 with burglary) there is a significant gap in request rates when compared to all other detainees.
} 
The extent to which legal advice requested was actually received

As noted above, of the $45.0 \%$ of juvenile detainees who requested legal advice, $74.9 \%$ obtained a legal consultation. For adults, $45.5 \%$ requested legal advice and $77.9 \%$ received such advice. Of those 10 to 13 year olds requesting legal advice, just $64.7 \%$ received such advice compared to $73.3 \%$ for 14 and 15 year olds and $78.1 \%$ for 16 and 17 year olds. Table 9 below sets out the rate at which requests were met for detainees of different ages. ${ }^{15}$ As can be seen, children aged 10 to 13 years were the least likely to have requests for legal advice fulfilled, apart from when receiving a pre-court disposal, when it is 14 and 15 year olds who are least likely to receive advice. In addition, apart from when no further action is taken, it is 10 to 15 year olds who are seen to have fewer requests for legal advice resulting in legal consultations when compared to those aged 16 years and older.

Table 9: Proportion of requests for legal advice that led to consultations by case outcome and age

\begin{tabular}{l|lllll}
\hline Advice received & \multicolumn{4}{l}{ Age } & \multicolumn{4}{l}{} \\
\cline { 2 - 6 } & $\begin{array}{l}18+ \\
\mathrm{n}=1963\end{array}$ & $\begin{array}{l}10-17 \\
\mathrm{n}=340\end{array}$ & $\begin{array}{ll}16-17 \\
\mathrm{n}=184\end{array}$ & $\begin{array}{l}14-15 \\
\mathrm{n}=111\end{array}$ & $\begin{array}{l}10-13 \\
\mathrm{n} 45\end{array}$ \\
& $\%$ & $\%$ & $\%$ & $\%$ & $\%$ \\
\hline No further action & 88.5 & 83.7 & 79.7 & 93.3 & 72.7 \\
Pre-court disposal & 80.1 & 71.4 & 85.7 & 60.0 & 69.2 \\
Charge & 77.9 & 70.5 & 76.9 & 62.7 & 61.9 \\
\hline
\end{tabular}

\section{Discussion}

Our analysis of police electronic custody records has highlighted wide variations in the takeup of legal advice. The take-up rate is influenced by various factors, including offence seriousness, offence type and the outcome of detention. Importantly, in the context of this study, variations were observed between detainees of different ages, including between juvenile detainees of different ages. Of particular concern, is the finding that 10 to 13 year olds, the most vulnerable age group, are the least likely to request and receive legal advice. Also, while the take-up of advice increases for all those who are charged, and is slightly higher for juveniles than adults in this case, $43 \%$ of juveniles do not request to see a solicitor despite going on to be charged.

A number of issues have arisen out of this analysis of police custody records which are explored further through four key themes: the role of appropriate adults, abolition of the presumption of doli incapax, the Final Warning scheme and the potential for police culture to impact on legal advice.

\section{The role of appropriate adults}

The vulnerability of children and young people detained in police stations in England and Wales was recognised in PACE and accordingly the legislation requires that all 10 to 16 year olds have an appropriate adult. Home Office guidance (2003) setting out the role of

\footnotetext{
15 There are lower numbers involved in this sub-sample of cases. For 10-13 year olds there are 51 cases, 120 for those aged 14 and 15, and 211 for those aged 16 and 17 years.
} 
appropriate adults, ${ }^{16}$ explicitly states that they are not to provide legal advice. Despite this, there is no similar mandatory requirement covering access to legal advice for those identified as vulnerable. While a parent or other relative can take on the role of the appropriate adult, there are also available professional and voluntary services. With these services tending to have a policy of asking for legal advice as a matter of course, this seems to have helped increase request rates for legal advice for juveniles accompanied by 'specialist' or familially independent responsible adults as distinct from parents/carers (Bucke and Brown, 1997; Brookman and Pierpoint, 2003).

As noted in Figure 1 above, while there is a significant increase in request rates for juveniles up to the age of 16, this then drops sharply for 17 year olds. It can be surmised that the marked decrease in requests for legal advice by 17 year olds is because there is, at present, no mandatory requirement for an appropriate adult. Such a supposition could be tested if the Home Office (2008 and 2010) implements the proposal to extend the requirement for appropriate adults to 17 year olds.

As appropriate adults (particularly specialist independent appropriate adults) have been found to be influential in increasing request rates for legal advice (Bucke and Brown, 1997; Brookman and Pierpoint, 2003; Pierpoint, 2004), then the question which arises is why this is not the case for 10 to 13 year olds? It is this age group which is most vulnerable, and so it is unfortunate that in a complex adversarial system of justice that they have the lowest take-up of legal advice. With such a young and vulnerable age group, it may be that relatives are more likely to take on the role as the appropriate adult. ${ }^{17}$ If so, while professional and voluntary services are aware of the importance of legal advice (Brookman and Pierpoint, 2003; Pierpoint, 2004), this is not always likely to be the case with relatives. Indeed, research has suggested that relatives of the accused are not always suitable to act as the appropriate adult. This is because they can adopt a 'passive and acquiescent' role in the police station, express 'hostility and distress' towards the child and put them under pressure to confess prior to the police interview (Dixon et al., 1990; Gudjonsson, 1993; Bucke and Brown, 1997; Hazel et al., 2002; Brookman and Pierpoint, 2003).

Research has also shown that for children detained by the police, a priority is to be released as quickly as possible (Littlechild, 1998; Pierpoint, 2008). Indeed, Littlechild noted that children 'are often in a destabilised state as a result of detention, and are very keen to be released at almost any cost as soon as possible' (1998:8). Unfortunately, while appropriate adults often provide important welfare protections for children and young people, a downside for the young detainee can be having to wait for them to attend at the police station. In one study, for example, while half of the appropriate adults appeared within one hour, $21 \%$ took two or more hours to attend (Phillips and Brown, 1998). ${ }^{18}$ More recently, Pierpoint (2008) noted that appropriate adult services provided by voluntary schemes seemed to be quicker than parents or professional services. She found that when voluntary workers were asked to attend at the police station as soon as possible, they had an average attendance time of 37

\footnotetext{
${ }^{16}$ The role of the appropriate adult is to assist and advise vulnerable detainees and to ensure that they understand what is happening to them and why. Appropriate adults are also required to ensure that the police are acting properly, fairly and with respect for their rights (see the Guidance for Appropriate Adults at Home Office (2003)).

${ }^{17}$ In previous studies, relatives were found to account for around two-thirds of appropriate adults (Bucke and Brown, 1997; Phillips and Brown, 1998).

${ }^{18}$ There were $7 \%$ of young detainees who were kept waiting for over four hours for the appropriate adult to attend (Phillips and Brown, 1998).
} 
minutes (ranging from taking no time at all to 3 hours and 15 minutes). ${ }^{19}$ If there are long delays while children and young people wait for an appropriate adult, then the thought of there being further delays could discourage them from requesting legal advice (Dixon et al., 1990). ${ }^{20}$

The difficulties encountered with appropriate adults, particularly in relation to access to legal advice, have led some critics to argue for a tightening up of legal protections, including for some, introducing mandatory legal advice for juveniles detained in police stations (Littlechild, 1998; Pierpoint, 2006; Kemp, 2010; Sanders, Young and Burton, 2010). However, it is important that both welfare and legal protections required for juveniles do not unduly increase their time spent in custody.

\section{Abolition of the presumption of doli incapax}

The presumption of doli incapax was introduced in the fourteenth century when it sought to protect children from the harsh effects of adult justice. More recently, as noted above, the presumption provided that a child aged 10 to 13 years was incapable of a crime unless the prosecution were able to rebut the presumption, by establishing that the child knew that what he or she was doing was seriously wrong. The presumption was abolished by the Crime and Disorder Act 1998, and children aged 10 to 13 years are now presumed to have the same mental capacity as older people (Bandalli, 1998 and 2000; Goldson and Muncie, 2006; Goldson, 2009). This means that from the age of 10, children are expected to fully participate in an adversarial system of justice where they are required to make decisions concerning their legal rights, including whether or not to have a solicitor. The exercise of such rights requires an informed decision, and as explored by Kemp (2010), it is unlikely that many adults, let alone children, are aware of the importance of having legal advice when detained in the police station.

Analysis of police electronic custody records reveal that 10 to 13 year olds behave differently from other detainees in that they are less likely to request and receive legal advice. While it is not known why this is so, there are a number of possible reasons. As discussed above, one reason could be if relatives are more likely to act as appropriate adults for children (Bucke and Brown, 1997; Phillips and Brown, 1998). Another possibility could be if the police tend to deal more sensitively with children and provide reassurances about what is likely to happen. Such reassurances could include their early release from custody, although as noted above, this could discourage young detainees from having legal advice if they believe that waiting for a solicitor could increase their time spent in custody (Littlechild, 1998; Dixon et al., 1990). As children are more likely to receive a pre-court disposal than be charged, this is another reassurance which the police could give to a child and their appropriate adult (Evans and Puech, 2001; Holdaway, 2003).

There are a range of international conventions, standards, treaties and rules which provide specified rights in respect of children and young people drawn into the youth justice system (see Goldson and Muncie, 2006; Goldson, 2009). When the Criminal Justice and Immigration Bill was being considered at the report stage in the House of Lords, concerns

\footnotetext{
${ }^{19}$ Interestingly, Pierpoint (2008) found a significant difference with those appropriate adults being asked to attend at a particular time, varying from taking no time at all to 4 hours and 30 minutes, with an average time of 1 hour and 52 minutes.

${ }^{20}$ See also Kemp (2010) for a discussion on how detainees' perceptions of having to wait for a solicitor can dissuade some from having legal advice.
} 
were raised by Earl of Onslow, Lord Thomas of Gresford, Baroness Falkner of Margravine and Lord Ramsbotham that there was no automatic right to legal representation in court proceedings (see Standing Committee for Youth Justice, 2008). ${ }^{21}$ In support of their argument the Lords cited Article 12 of the United Nations Convention on the Rights of the Child, where it requires that in judicial proceedings children are to 'be heard' and to 'effectively participate' (as required in law), which requires them having access to good quality legal representation. ${ }^{22}$ The Parliamentary Joint Committee on Human Rights (2007: Para 1.24:5 ${ }^{\text {th }}$ report) also recommended that the Government should amend the Bill to provide for a general right of legal representation for children in criminal proceedings. However, with seemingly high levels of legal representation in Youth Courts, the Government felt that no amendments were necessary at that time. Interestingly, while the House of Lords was satisfied with the level of representation in the Youth Courts, they did not consider the extent to which juveniles have a lower take-up of legal advice in police stations. $^{23}$

\section{The Final Warning scheme}

The Final Warning scheme was introduced after concerns were raised over the multiple use of cautioning as a means of diverting young offenders from court, which was said to have brought the disposal into disrepute (Evans, 1994a). ${ }^{24}$ The new scheme imposes a rigid approach to decision-making with just one reprimand being allowed followed by one warning prior to charge (see Home Office, 2006). ${ }^{25}$ The stated intention of the Final Warning scheme is to 'nip offending in the bud', by making it known to juveniles that they cannot keep offending without serious consequences (Home Office, 1997). While the scheme allows for a 'three-step' approach, in practice, the majority of child offenders are found not to have the two pre-court disposals and instead are charged for a first offence (Audit Commission, 2004; Holdaway and Desborough. 2004). ${ }^{26}$

The Final Warning scheme adopts a punitive approach with potentially serious consequences for those receiving a reprimand or warning. Indeed, as Gillespie (2005) points out, a reprimand or warning contains many of the characteristics of a conviction because these are recorded on the Police National Computer and with any subsequent offence the child takes a step up the prosecution tariff (Holdaway, 2003). In addition, if reprimanded or warned for a sexual offence, the child's details can be noted on the sex offenders' register

\footnotetext{
${ }^{21}$ The Lords were particularly concerned about the introduction of the new Youth Rehabilitation Order (which combines a number of sentences into one generic sentence) and they proposed that a child or young person should be represented before such an Order was made.

${ }^{22}$ The right to legal representation was also considered to be important to ensure that any waiver of the right to legal representation was made on a properly informed basis and with the appropriate safeguards in place (Standing Committee for Youth Justice, 2008).

${ }^{23}$ There are no statistics available on the extent to which either juveniles or adults are represented in magistrates' courts. In Kemp's study (2008) of 166 cases dealt with in Youth Courts, 92\% were represented in court but just over half in police stations.

24 The research evidence did not support this argument, with only a small number of young offenders $(8 \%)$ receiving more than two cautions (Home Office, 1994).

${ }^{25}$ As an exception, a second warning can be imposed if the previous warning was recorded over two years ago (Home Office, 2006).

${ }^{26}$ In Kemp's study (2008) of 166 young people prosecuted, $22 \%$ of cases were withdrawn from court because they were found to be eligible for either a reprimand or warning. In another study, it was noted that over half of those who pleaded guilty and received a Referral Order (which is normally the disposal for first-time offenders) had not previously received a reprimand or warning (cited in the Audit Commission report (2004).
} 
(see R v Durham Police and another, ex parte R). ${ }^{27}$ There are other potential long-term consequences, with Home Office and Youth Justice Board (2002) guidance stating that the record of a reprimand or warning can be made available to potential employers in certain circumstances. $^{28}$ Despite these potentially serious consequences, it has been found that only around a quarter of juveniles requested legal advice when receiving a pre-court disposal.

There are legal criteria which have to be met before a reprimand or warning can be recorded. The first is that there is sufficient evidence that the young person has committed the offence and, if prosecuted, there would be a realistic prospect of conviction. The second requires the police to ensure that the young person has made a clear and reliable admission to all elements of the offence (Home Office, 2006). It was noted under the juvenile cautioning scheme that these preconditions were often ignored and that some suspects were cautioned precisely because there was insufficient evidence to prosecute (Sanders, 1988; McConville et al., 1991; Evans, 1994b). In addition, Leng found that with police officers and lawyers considering juvenile cautions to be a 'let-off' that little attention was paid to the legal criteria (cited in Evans and Puech, 2001).

Research into the Final Warning scheme has similarly found that the legal criteria are not always met, despite the more serious consequences which can now follow (Evans and Puech, 2001; Holdaway, 2003; Hine, 2007). With only around one-quarter of detainees requesting legal advice there is no opportunity provided for an independent scrutiny of the evidential requirements. However, in some cases where legal advice has been received, there has been a disregard for due process by both police officers and legal advisers (Evans and Puech, 2001; Holdaway, 2003). Indeed, it is inappropriate that some legal advisers have put young people under pressure to admit offences, even in ambiguous circumstances, as they consider it preferable to have a pre-court disposal in order to avoid a court hearing (Holdaway, 2003). ${ }^{29}$ With the potentially serious consequences of receiving a reprimand or warning it is important to ensure that there are mechanisms in place with allow for a review of the evidence and that these disposals are only imposed in cases when the legal criteria are clearly met (Evans and Puech, 2001).

Another legal criterion which the police have to consider before recording a reprimand or warning is whether it is in the public interest. Under the Final Warning scheme, this criterion is considered to be met through the police use of gravity scores, which are used to determine the seriousness of offences (Home Office, 2006). ${ }^{30}$ While the use of the Gravity Factor System is intended to meet the requirements of the public interest test, research has found inconsistencies in the way police apply the scores, including the system being ignored altogether by some police officers who instead rely on their experience and 'commonsense' (Evans and Puech, 2001; Holdaway, 2003).

A further limitation when using gravity scores in determining the seriousness of the offence, is that this relies on a typology of offence types, with some categories being too

\footnotetext{
27 [2005] UKHL2

${ }^{28}$ The circumstances are fairly broad including employment which involves work with children, the sick, the vulnerable, the administration of justice or where issues of financial probity are in question (Home Office, 2002).

${ }^{29}$ It has also been noted that children and their parents prefer to receive a warning rather than go to court, although this was seen to be the lesser of two evils (Evans and Puech, 2001).

${ }^{30}$ There is a gravity score attached to most offence types and the police are able to increase or decrease by one point the gravity score depending on any aggravating or mitigating factors (Home Office, 2006).
} 
broad. For the offence of 'robbery', for instance, this carries the maximum penalty of life imprisonment, although the behaviour complained of can vary significantly, ${ }^{31}$ particularly when involving children and young people. There are also occasions where research has found children and young people being reprimanded or warned not only for trivial matters but also for non-criminal behaviour which could otherwise be described as 'childish' and 'childlike' (Holdaway, 2003; Audit Commission, 2004; Hine, 2007; Kemp, 2008). ${ }^{32}$ Without sufficient legal safeguards, pre-charge decision-making under the new Final Warning scheme has been criticised for providing a highly discretionary process rooted in personal judgements (Evans and Puech, 2001; Holdaway, 2003; Field, 2008).

\section{Police culture and attitudes towards legal advice}

There have been found to be wide variations in request rates for legal advice depending on both the police stations involved and also police force areas (Bucke and Brown, 1997; Phillips and Brown, 1998; Pleasence et al., 2011). Research has identified a number of factors which can influence request rates for legal advice in police stations. Having been held in custody over a long period of time during the police investigation, for instance, can put pressure on detainees to be released as quickly as possible and thereby forego legal advice (Dixon et al., 1990; Bucke and Brown, 1997; Hine, 2007; Skinns, 2009a; Kemp, 2010). It has also been suggested that police 'ploys' are used at some stations in order to discourage detainees from requesting legal advice (Sanders et al., 1989; Kemp, 2010). However, it is important to bear in mind, that when over 1,000 people drawn into the criminal justice system (aged 17 years and older) were asked why they had declined to have legal advice in the police station, the majority said they 'did not need' a solicitor (Kemp and Balmer, 2008; Kemp, 2010). While the police are in a position to influence both lower and higher request rates for legal advice, the decision to refuse legal advice is often one made by detainees of their own accord. Nevertheless, it is important to examine further the reasons why children and young people decline police station legal advice, and also the extent to which detainees are in a position to make informed decisions when exercising their legal rights. Other factors which have been found to influence request rates for legal advice include the local market for criminal defence services and relationships between police officers and legal advisers (Skinns, 2009a and 2009b and Kemp, 2010).

Further research is currently being undertaken in order to better understand the factors which influence request rates for legal advice. This will include observation of police custody suites, with police stations identified in this study with a high or low request rate in the four police force areas selected. The study will also seek to include interviews with detainees, custody officers and legal advisers about what factors they consider to be important in relation to police station legal advice.

\section{Statistical Appendix}

Table A below shows the statistical output from the regression analyses modelling the likelihood of requesting a solicitor. Each explanatory variable has a reference category, to

\footnotetext{
${ }^{31}$ As Ashworth (2002) points out, such behaviour can range from a borderline theft where someone tugs at a handbag in such a way that the owner's hand is pulled downwards, to a robbery of a security van with guns being fired.

32 There are cases where children have been warned for offences when, based on their version of events, there is raised the possibility of a defence. Having been arrested for theft, for example, there are cases where the young person clearly thought the items taken had been abandoned. Fights been young friends can also raise important issues concerning guilt (see Holdaway, 2003 and Hine, 2007).
} 
which other categories are compared. For example, in the case of area, areas B, C and D are compared to area A (the reference category). Reference categories can be identified by the fact that they have an estimate of zero and no standard error in the output tables. Positive estimates indicate an increased rate of requesting advice, compared to the reference category, while negative estimates indicate a decreased rate. The standard error can be used to determine whether any indicated increase/decrease is statistically significant (i.e. is likely/not likely to be the product of chance). In Table A statistically significant findings are indicated in bold. The final columns of Table A set out odds ratios, which indicate the relative odds of requesting advice, as compared to the reference category. Odds ratios vary around 1 (which would indicate no change). Odds ratios above 1 indicate an increased likelihood, and below 1 a decreased likelihood of requesting/obtaining advice. So offences with a gravity score of ' 4 ', (with an odds ratio of 5.81) were more than 5 times as likely to involve a request for advice rather than no request for advice when compared to offences with a gravity score of ' 1 ' (the reference category). In contrast, respondents aged 11 (with an odds ratio of 0.82 ) were around 20 percent less likely than the reference category (17 year olds) to request advice rather than fail to request advice. However, as the terms for 11 year olds are not highlighted in bold, this difference was not statistically significant.

Table A: Regression modelling the likelihood of requesting a solicitor

\begin{tabular}{|c|c|c|c|c|}
\hline Parameter & Category & Estimate & SE & $\begin{array}{l}\text { Odds } \\
\text { Ratio }\end{array}$ \\
\hline \multicolumn{5}{|l|}{ Fixed effects } \\
\hline Constant & & -1.87 & 0.28 & \\
\hline \multirow[t]{8}{*}{ Age } & 10 & -1.28 & 1.07 & 0.28 \\
\hline & 11 & -0.2 & 0.41 & 0.82 \\
\hline & 12 & 0.27 & 0.24 & 1.31 \\
\hline & 13 & -0.05 & 0.18 & 0.95 \\
\hline & 14 & 0.27 & 0.14 & 1.31 \\
\hline & 15 & 0.24 & 0.12 & 1.27 \\
\hline & 16 & 0.6 & 0.11 & 1.82 \\
\hline & 17 & 0 & - & \\
\hline \multirow[t]{2}{*}{ Gender } & Male & 0 & - & \\
\hline & Female & -0.17 & 0.1 & 0.84 \\
\hline \multirow[t]{7}{*}{ Ethnic appearance } & White - North European & 0 & - & \\
\hline & White - South European & 0.27 & 0.29 & 1.31 \\
\hline & Middle Eastern & -0.27 & 0.5 & 0.76 \\
\hline & Asian & 0.4 & 0.27 & 1.49 \\
\hline & Black & 0.57 & 0.15 & 1.77 \\
\hline & Chinese etc & 2.35 & 1.27 & 10.49 \\
\hline & Unknown & -0.24 & 0.45 & 0.79 \\
\hline \multirow[t]{4}{*}{ Area } & $\mathrm{A}$ & 0 & - & \\
\hline & $\mathrm{B}$ & -0.14 & 0.18 & 0.87 \\
\hline & $\mathrm{C}$ & 1.03 & 0.17 & 2.80 \\
\hline & $\mathrm{D}$ & 0.74 & 0.17 & 2.10 \\
\hline \multirow[t]{4}{*}{ Gravity score } & 1 & 0 & - & \\
\hline & 2 & 0.54 & 0.27 & 1.72 \\
\hline & 3 & 0.99 & 0.27 & 2.69 \\
\hline & 4 & 1.76 & 0.28 & 5.81 \\
\hline
\end{tabular}




\begin{tabular}{|l|l|l|l|l|}
\hline Random effects & & & & \\
\hline Person level & & $\mathbf{1 . 8 7}$ & $\mathbf{0 . 1 4}$ & $\mathbf{6 . 4 9}$ \\
\hline Police station level & & $\mathbf{0 . 0 9}$ & $\mathbf{0 . 0 4}$ & $\mathbf{1 . 0 9}$ \\
\hline
\end{tabular}

\section{References}

Ashworth, A. (2002) 'Robbery re-assessed' in Criminal Law Review, 11: 851-872.

Audit Commission (2004) Youth Justice 2004: A review of the reformed youth justice system. London: Audit Commission.

Bandalli, S. (1998) 'Abolition of the presumption of doli incapax and the criminalisation of children' in The Howard Journal, Vol. 37/2: 114-123.

Bandalli, S. (2000) 'Children, Responsibility and the New Youth Justice' in B. Goldson (ed) The New Youth Justice. Lyme Regis: Russell House Publishing.

Bottomley, K., Coleman, C., Dixon, D., Gill, M. and Wall, D. (1989) The impact of aspects of the Police and Criminal Evidence Act 1984 on Policing in a Force in the North of England. Final report to the ESRC. Unpublished.

Brookman, F., and Pierpoint, H. (2003). 'Access to Legal Advice for Young Suspects and Remand Prisoners', The Howard Journal of Criminal Justice, Vol. 42/5, 452-470.

Brown, D. (1989) Detention at the Police Station under the Police and Criminal Evidence Act 1984. Home Office Research Study No. 104. London: HMSO.

Brown, D. (1991) Investigating Burglary: The effects of PACE. Home Office Research Study No.123. London: Home Office.

Brown, D., Ellis, T. and Larcombe, K. (1992) Changing the Code: Police Detention under the Revised PACE Codes of Practice. Home Office Research Study No. 129. London: Home Office.

Bucke, T. and Brown, D. (1997) In police custody: police powers and suspects' rights under the revised PACE Codes of Practice. Home Office Research Study 174. London: Home Office.

Dixon, D., Bottomley, K., Coleman, C., Gill, M. And Wall, D. (1990) 'Safeguarding the rights of suspects in police custody' in Policing and Society, Vol. 1:115-140.

Evans, R. (1994a), 'Cautioning: Counting the Cost of Retrenchment', Criminal Law Review, 8: $566-575$.

Evans, R. (1994b) 'Police interrogations and the Royal Commission on Criminal Justice' in Policing and Society, Vol. 4/1: 73-81. 
Evans, R. and Puech, K. (2001) 'Reprimands and warnings: Populist punitiveness or restorative justice?' in Criminal Law Review, 10: 794-805.

Field, S. (2008) 'Early intervention and the 'New' Youth Justice: a study of initial decisionmaking' in Criminal Law Review, 3: 177-190.

Gillespie, A. (2005) 'Reprimanding juveniles and the right to due process' in Modern Law Review, Vol. 68: 1006-1015.

Goldson, B. (2000) 'Wither diversion? Interventionism and the New Youth Justice', in B. Goldson (ed) The New Youth Justice. Lyme Regis: Russell House Publishing.

Goldson, B. (2009) ' Difficult to understand or defend': a reasoned case for raising the age of criminal responsibility' in The Howard Journal, Vol. 48/5:514-521.

Goldson, B. and Muncie, J. (2006) 'Critical anatomy: Towards a principled youth justice' in B. Goldson and J. Muncie (eds) Youth crime and justice. London: Sage Publications.

Gudjonsson, G. (1993) 'Confession Evidence, Psychological Vulnerability and Expert Testimony’ in Journal of Community and Applied Social Psychology, Vol. 3 (2): 117-129.

Hazel, N., Hagell, A. and Brazier, L. (2002) Young offenders' perceptions of their experiences in the criminal justice system. London: Policy Research Bureau.

Hine, J. (2007) 'Young people's perspectives on final warnings' in Web Journal of Current Legal Issues, 2. Accessed at: http://webjcli.ncl.ac.uk/2007/issue2/hine2.html.

Holdaway, S. (2003) 'Final warning: Appearance and reality' in Criminology and Criminal Justice, Vol. 3/4: 351-367.

Holdaway, S. and Desborough, S. (2004) Final warning projects. London: Youth Justice Board.

Home Office (1994) The Criminal Histories of those Cautioned in 1985, 1988 and 1991. London: HMSO.

Home Office (1996) Criminal Statistics, England and Wales 1995. London: HMSO.

Home Office (1997) No More Excuses: A New Approach to Tackling Youth Crime in England and Wales, Cmnd 3809. London: HMSO.

Home Office and Youth Justice Board (2002) Final Warning Scheme: Guidance for the police and youth offending teams. London: Home Office.

Home Office (2003) Guidance for Appropriate Adults. Accessed at: http://police.homeoffice. gov.uk/ publications.

Home Office (2006), 'The Final Warning Scheme', Circular 14/2006: Guidance for the Police and Youth Offending Teams. London: Home Office. 
Home Office (2008) PACE Review: Government proposals in response to the review of the Police and Criminal Evidence Act 1984. London: Home Office.

Home Office (2010) PACE Review: summary of responses to the public consultation on the review of the Police and Criminal Evidence Act 1984. London: Home Office.

Joint Committee on Human Rights (2007) Legislative scrutiny: Criminal Justice and Immigration Bill. 22rd Report of session 2007-08.

Kemp, V. (2008) A scoping study adopting a 'whole-systems' approach to the processing of cases in the Youth Courts. Research Paper No. 24. London: Legal Services Research Centre. Accessed at: http://lsrc.org.uk/publications.

Kemp, V. (2010) Transforming legal aid: access to criminal defence solicitors. London: Legal Services Research Centre. Accessed at http://lsrc.org.uk/publications.

Kemp, V. and Balmer, N. (2008) Criminal defence services: users' perspectives. An Interim Report. Research Paper No. 21. London: Legal Services Research Centre. Accessed at: http://lsrc.org.uk/ publications.

Littlechild, B. (1998) 'An end to 'Inappropriate Adults'? in C hildright, Vol. 144: 8-9.

McConville, M., Sanders, A. and Leng, R. (1991) The case for the prosecution. London: Routledge.

Morgan, R. (2008) Summary justice: fast - but fair? London: Centre for Crime and Justice Studies. Accessed at: http://www.crimeandjustice.org.uk/opus784/Summary-justice.pdf.

Phillips, C. And Brown, D. (1998) Entry into the criminal justice system: a survey of police arrest and their outcomes. Home Office Research Study 185. London: Home Office.

Pierpoint, H. (2004) 'A Survey on Volunteer Appropriate Adult Services', Youth Justice, Vol. 4(1), 32-45.

Pierpoint, H. (2006) 'Reconstructing the Role of the Appropriate Adult in England and Wales', Criminology and Criminal Justice, Vol. 6/2: 219-238.

Pierpoint, H. (2008) 'Quickening the PACE: The Use of Volunteers as Appropriate Adults', Policing and Society, Vol.18/4: 397-410.

Pleasence, P., Kemp, V. and Balmer, N.J. (2011) 'The Justice Lottery? Police station advice 25 years on from PACE' in Criminal Law Review (2001:1).

Sanders, A. (1988) 'The limits to diversion from prosecution', British Journal of Criminology, 28:513-32).

Sanders, A., Bridges, L., Mulvaney, A. and Crozier, G. (1989) Advice and Assistance in Police Stations and the 24-Hour Duty Solicitor Scheme, London: Lord Chancellor's Department. 
Sanders, A., Young, R. and Burton, M. (2010) Criminal Justice, 4th edn, London: Oxford University Press.

Skinns, L. (2009a) 'I'm a detainee: get me out of here'. British Journal of Criminology, vol. 49(3), pp. 399-417.

Skinns, L. (2009b) 'Let's Get it Over With: Early Findings on the Factors Affecting Detainees' Access to Custodial Legal Advice, 19(1) Policing and Society, pp.58-78.

Softley, P., with the assistance of Brown, D., Forde, B., Mair, G. and Moxon, D. (1980) Police Interrogation: an observational study in four police stations. Home Office Research Study No. 61. London: HMSO.

Standing Committee for Youth Justice (2008) Criminal Justice and Immigration Bill - House of Lords Report stage briefing re youth rehabilitation order: legal representation (II). Accessed at: http://www.scyj.org.uk/files/CJIB_LRept_Legal_repii_final.pdf.

Youth Justice Board and Ministry of Justice (2010) Youth justice annual workload data 2008/09: England and Wales. London: Ministry of Justice. 